\title{
Burial and uplift history of the Palaeozoic Flysch in the Variscan foreland basin (SE Bohemian Massif, Czech Republic)
}

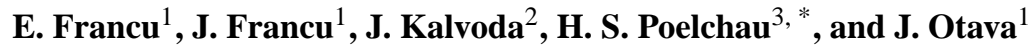 \\ ${ }^{1}$ Czech Geological Survey, Leitnerova 22, 65869 Brno, Czech Republic \\ ${ }^{2}$ Dept. of Geology, Masaryk University, Kotlárská 2, Brno, Czech Republic \\ ${ }^{3}$ Inst. für Chemie und Dynamik der Geosphäre, Forschungszentrum Jülich, 52425 Jülich, Germany \\ * currently at: Kansas Geological Survey, USA
}

Received: 4 April 2001 - Revised: 15 October 2001 - Accepted: 29 October 2001

\begin{abstract}
Organic and clay indicators were measured to characterise the burial and thermal history of Devonian through Upper Carboniferous siliciclastic and carbonate rocks in the Rheno-Hercynian zone of the Variscan orogeny in Moravia (eastern Czech Republic). The very low-grade metamorphism is documented by the illite crystallinity (IC) and vitrinite reflectance $\left(R_{r}\right)$ in the inner part of the thrust and fold belt in the NNW. Application of forward thermal modelling suggests maximum palaeo-temperature of $240-360^{\circ} \mathrm{C}$ and burial depth of 4-9 km. In the Variscan foreland in the SSE the IC and $R_{r}$ values are typical of diagenetic conditions with maximum palaeo-temperature of $80-130^{\circ} \mathrm{C}$. The distribution of both clay and organic maturity parameters is interpreted as a result of pre- and syn-tectonic thermal exposure of the rocks due to burial by a wedge-shaped body of thrust sheets thinning towards the Variscan foreland where only sedimentary burial was effective. The amount of uplift and denudation increases from the foreland to the RhenoHercynian thin-skinned thrust and fold belt.
\end{abstract}

Key words. Vitrinite reflectance; illite crystallinity; modelling; thermal history; Variscan thrusting; erosion

\section{Introduction}

Significant advances have been made in understanding the causes and processes of diagenesis and metamorphism related to thermal history of sedimentary basins and thrust and fold belts (Tissot and Welte, 1984; Robert, 1988; Merriman and Frey, 1999). It is generally accepted that the burial depth, geothermal gradient and geological time play important roles in these processes and that lack of one may partly be compensated by surplus of the other factor. Mathematical methods have been proposed to calculate the probable maximum palaeo-temperature and palaeo-geothermal gradients in sedimentary basins from the coal rank and slope of the diagenetic

Correspondence to: E. Francu (francu@cgu.cz) or very low-grade metamorphic trend with depth in continuous profiles (Waples, 1980; Buntebarth, 1982; Barker, 1996).

The reconstruction of the burial history and palaeogeothermal conditions is much more complex when thrusting is involved and the (meta-)sedimentary rocks are imbricated and stacked. Fast underthrusting of cold crustal surface below overriding nappe sheet causes lowering of geothermal gradient in frontal orogenic belts. In result, tectonic burial is often asociated with lower or equal but not higher thermal stress than a pure sedimentary burial of the same thickness (Angevine and Turcotte, 1983; Wygrala et al., 1990; Čermák and Bodri, 1996).

The thermal history of the Palaeozoic in the SE Bohemian Massif has been a matter of discussion by different authors (e.g. Skoček, 1976; Dvořák, 1989). The results of our studies differ from the earlier ones in the following aspects:

- regional distribution of palaeo-geothermal gradient or heat flow

- amount of eroded sedimentary strata

- extent of tectonic displacement of the units (autochthonous vs. allochthonous position).

Several computer programmes were developed to formulate mathematically the geological concept of basin evolution and to simulate subsidence, geothermics and diagenesis (Tissot and Welte, 1984; Welte and Yalçin, 1988; Issler and Beaumont, 1989; Ungerer et al., 1990; Poelchau et al., 1997; Yalçin et al., 1997). In this paper the forward modelling approach is applied to simulate the geological history as a series of stratigraphic and tectonic events under evolving thermal conditions and to describe quantitatively deposition, non-deposition, and erosion in time. The changes of thickness of the preserved and missing strata (corrected for compaction) are represented by burial history curves. Deposition and erosion of the non-preserved units are inferred from unconformities, paleogeography, tectonics, and coalification discontinuities. The thickness of the eroded units and 


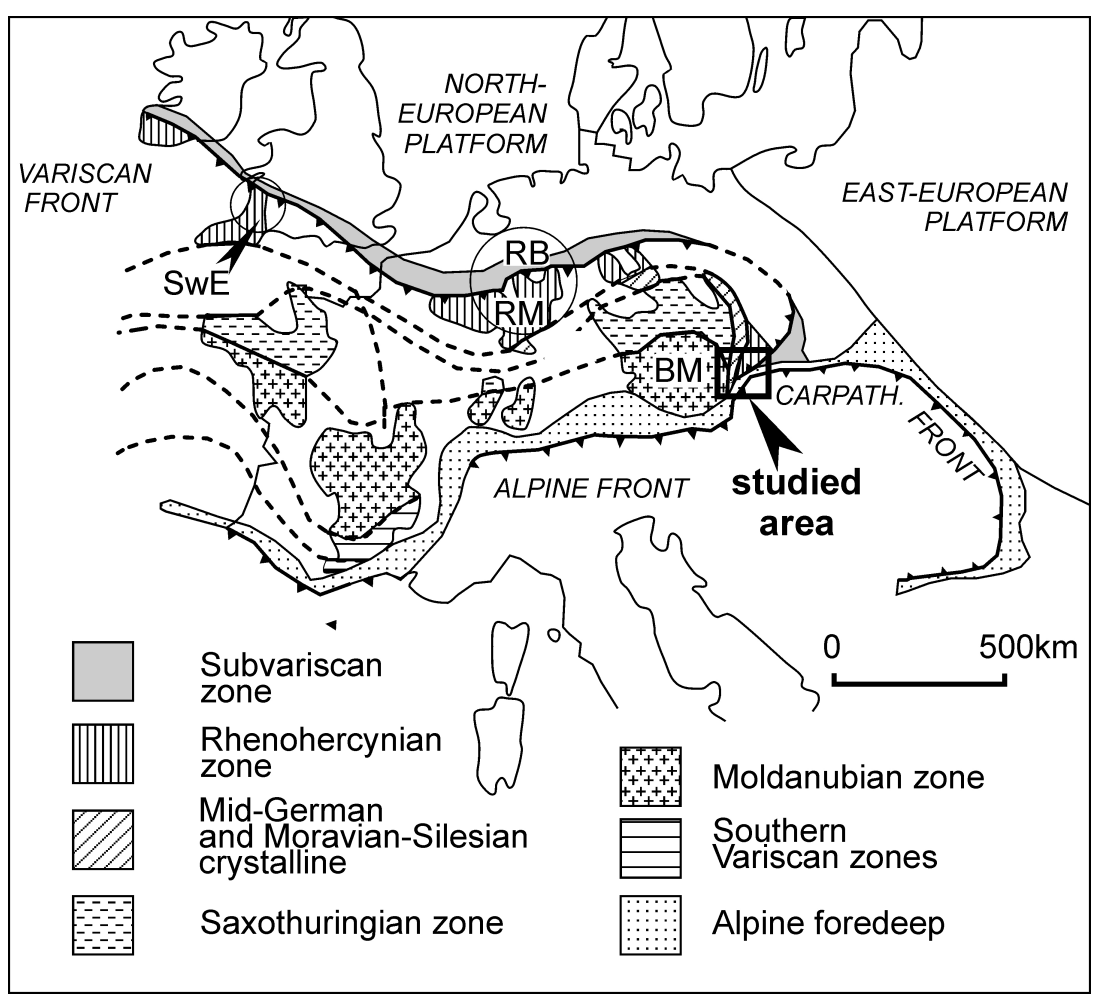

Fig. 1. Major zones of the Variscan orogenic belt and foreland in Europe (modified after Ellenberger, Tamain, 1980 and Mísař et al., 1983). Rectangle shows the studied area, and the circles represent the compared regions of the Rhenish Massif (RM), Ruhr Basin (RB), and Southwest England (SwE).

palaeo-heat flow data are iteratively estimated in the process of calibration (e.g. Poelchau et al., 1997) where the organic maturity is calculated using a kinetic approach (EASY\% $\mathrm{R}_{\mathrm{o}}$ of Sweeney and Burnham, 1990). The model is considered close to reality when the calculated vitrinite reflectance trend fits the measured data points.

\section{Geological setting}

The Palaeozoic in the eastern part of the Bohemian Massif (Fig. 1) is regarded as a part of the Rheno-Hercynian Zone of the Variscan orogenic belt (Franke, 1989). The Palaeozoic sequences in south-eastern Moravia are known from the outcrops in the Drahany Upland north of Brno and from deep boreholes below the Carpathian Foredeep and the overthrust of the West Carpathian Flysch Belt (Fig. 2). The crystalline basement is built by the Cadomian Brunovistulian terrane derived from the northern part of Gondwana (Finger and Steyrer, 1995) and includes the granitoids and metabasalts of the Brno Massif which are exposed at the surface in the SW. The lithostratigraphy (Fig. 3) of the studied basins starts with isolated occurrences of the Early Cambrian in the SE (Vavrdová, 1997; Jachowicz and Přichystal, 1997) and Silurian near Stínava in the NE. The main sedimentary sequences consist of a series of pre-flysch formations, Variscan flysch ("Culm") and marginal foreland sediments ("molasse"). The transgressive basal clastics of the Lower and Middle Devo- nian occur in the entire area. During the Middle Devonian to Lower Carboniferous carbonates and siliciclastics were deposited in a passive margin setting with a hiatus from the Tournaisian to middle Visean within the Lišen Fm. in the SE. The carbonates crop out in a narrow belt of the Moravian Karst north of Brno (Fig. 2) while most of the surface geology of the Drahany Upland exposes the Variscan synorogenic flysch of Early Carboniferous (Visean) age. Further to the SSE the Upper Carboniferous coal-bearing molasse sediments occur below the autochthonous Mesozoic, Tertiary and the nappes of the Outer Carpathians. More details about sedimentology, paleontology and tectonics are given e.g. by Hladil et al. (1992), Kalvoda (1994), Dvořák (1995), Kumpera and Martinec (1995), Hartley and Otava (2001).

\section{Earlier studies of thermal and erosion history}

The published data on thermal maturity of organic matter (coalification rank) and clays in the studied area include:

1. volatile matter $\left(\mathrm{V}^{\mathrm{daf}}\right)$ published mostly in technical reports and summarised by Dvořák and Skoček (1975, 1976);

2. vitrinite reflectance $\left(\mathrm{R}_{\max } \%\right)$ (see Dvořák and Wolf, 1979; Dvořák, 1989; Dvořák et al., 1997). 


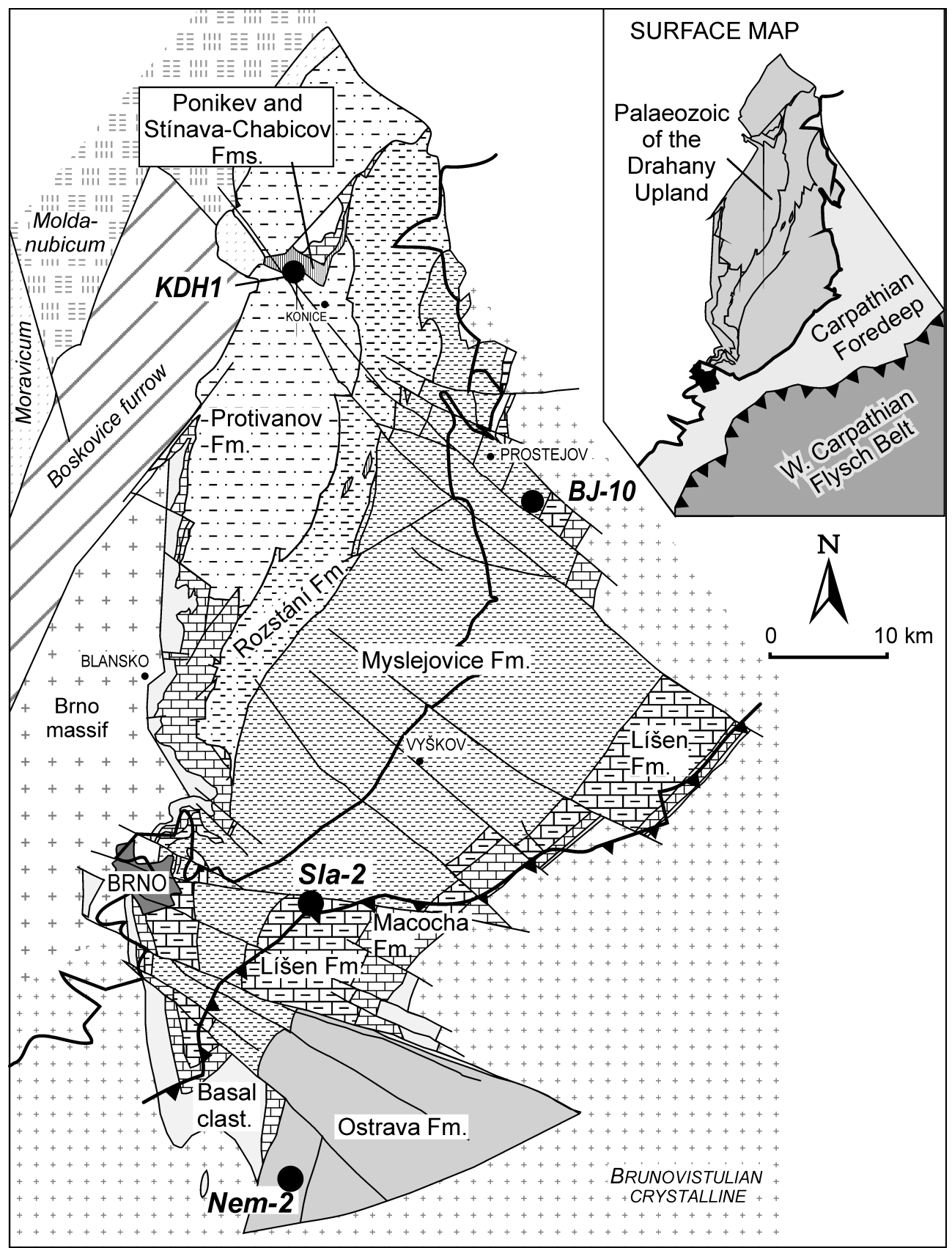

Fig. 2. Geological outcrop and subcrop map of the Palaeozoic and underlying crystalline of the SE margin of the Bohemian Massif with the locations of the modelled borehole profiles. Modified after Dvořák (1995).

3. illite crystallinity $\left(\mathrm{Hb}_{\mathrm{rel}}\right)$ (see Dvořák, 1989) in the NE continuation of the Moravo-Silesian Palaeozoic outside the area shown in Fig. 2.

A general increase of thermal maturity from SE to NW has been observed in the regional distribution of $\mathrm{R}_{\max }$ and $\mathrm{Hb}_{\text {rel }}$ (Dvořák and Wolf, 1979; Dvořák, 1989; Krejčí et al., 1994, 1996). Dvořák (1989) admitted that a simple extrapolation of the coalification trend to the original surface $R_{r}$ values would suggest erosion of $1000 \mathrm{~m}$ in the foreland and "many" kilometres in the thrust-and-fold belt but rejected such a hypothesis as paleo-geographically unsustainable. He assumed that "presence of redeposited metamorphosed Devonian rocks as pebbles in the Upper Viséan flysch gave evidence against existence of thick Palaeozoic units". Dvořák (1995) hypothetised that the Variscan orogeny was associated with high temperature - low pressure conditions and possible geothermal gradients of $70-90^{\circ} \mathrm{C} / \mathrm{km}$ in the foreland and over $200^{\circ} \mathrm{C} / \mathrm{km}$ in the "intramontane region" (West of Drahany Upland) associated with extensive hydrothermal activity. Dvořák (1995) did not present any mathematical models to justify his palaeo-geothermal assessments. 


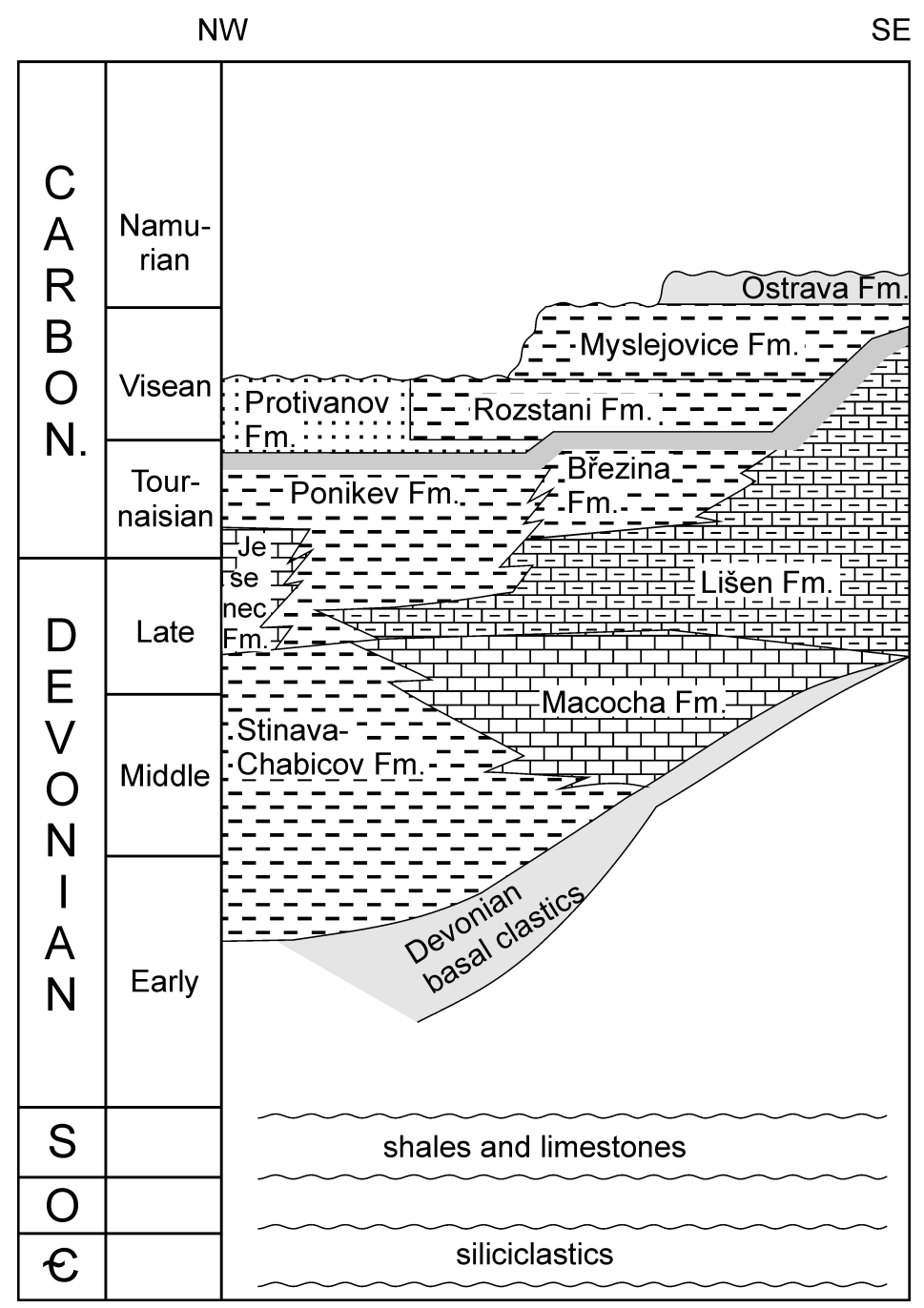

Fig. 3. Lithostratigraphy of the Palaeozoic in the Drahany Upland (modified after Dvořák, 1995). NW and SE directions related to the present geography.

Up to now, numerical models of thermal history have been applied in two adjacent areas. In the Late Palaeozoic Upper Silesian Basin, situated about $100 \mathrm{~km} \mathrm{NE}$ of the studied area, the palaeo-geothermal gradient was calculated using the method of Buntebarth $(1978,1982)$ to be as high as $95^{\circ} \mathrm{C} / \mathrm{km}$ and additional burial and erosion of $2-3 \mathrm{~km}$ (Šafanda et al., 1991). In the Nemcicky basin SE of the Drahany Upland forward models have recently been established by Francu et al. (1996) and Krejčí et al. (1996) and suggest only mildly elevated palaeo-heat flow values. No basin modelling was applied in the Drahany Upland up to now.

\section{Analytical methods}

\subsection{Sampling}

Samples of dark shales, slates or shaly interlayers in carbonates were collected from fresh outcrops and borehole cores. Key localities are shown in Fig. 4 and often include several measured data populations. The total number of sampling sites is higher than shown.

\subsection{Vitrinite reflectance}

The measurement of reflectance was carried out in oil on polished surfaces using a Leitz Wetzlar MPV2 microscopephotometer, with a 50x objective and Leitz standards of 1.26 and $5.42 \%$ reflectance, in non-polarised $\left(\mathrm{R}_{\mathrm{r}}\right)$ and planepolarised light $\left(\mathrm{R}_{\max }\right.$ and $\left.\mathrm{R}_{\min }\right)$. In order to obtain a single parameter for the entire range of thermal maturity, the $R_{\max }$ and $R_{\min }$ values of particles with higher bireflectance were recalculated to random reflectance using the equation $R_{r}=$ $\left(2 * \mathrm{R}_{\max }+\mathrm{R}_{\min }\right) / 3$ (Teichmüller et al., 1998). The applicability of this equation was verified by a series of measurements under both conditions. 


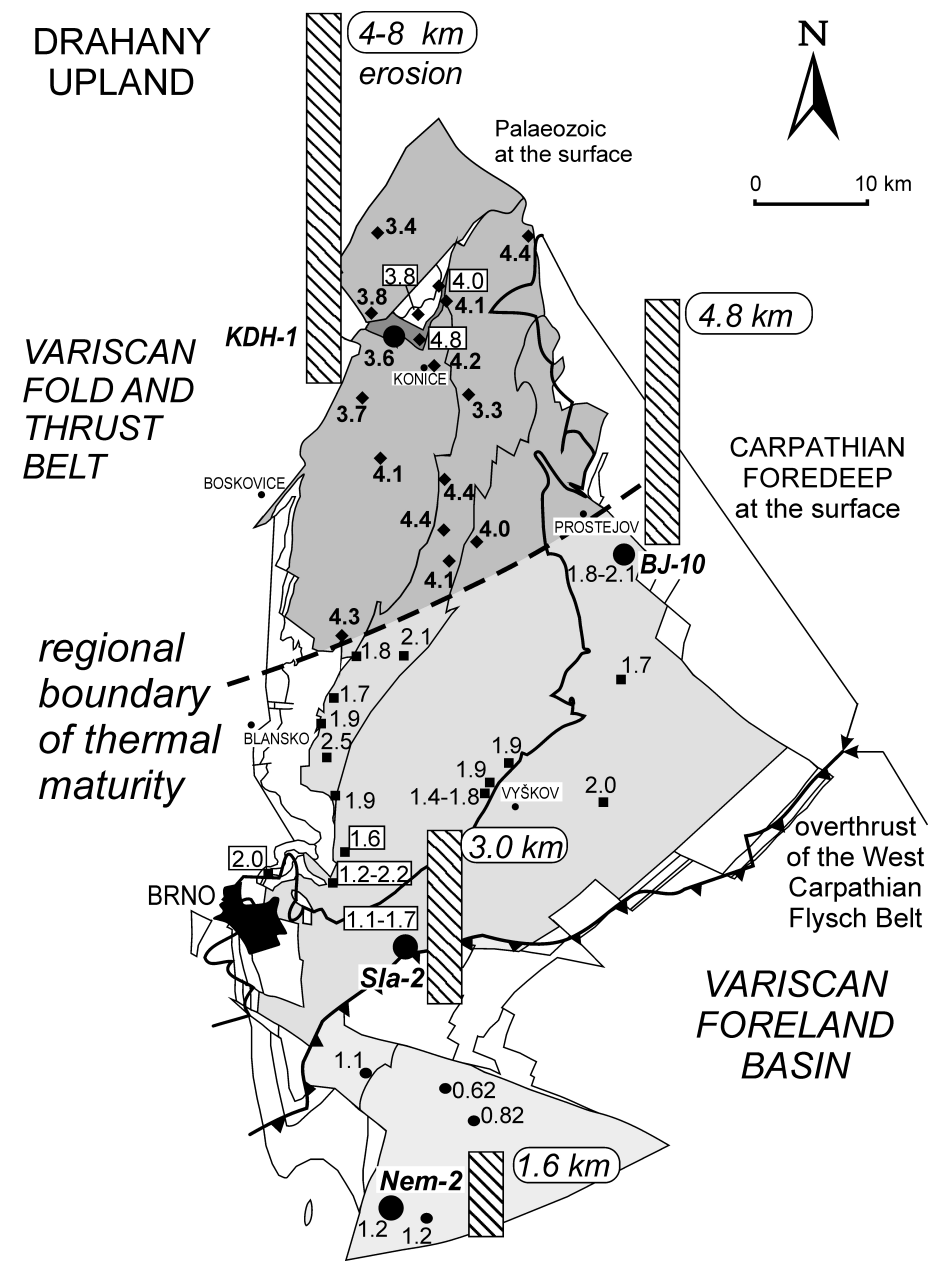

Fig. 4. Distribution of random vitrinite reflectance $\left(\mathrm{R}_{\mathrm{r}} \%\right)$ as a measure of thermal maturity in the Palaeozoic of the south-eastern Bohemian Massif (for geology see Fig. 2). The data are related to the Variscan flysch ("Culm"), those in rectangles to the pre-flysch units. Columns and values in rounded boxes show the thickness of the eroded overburden calculated using thermal modelling (relative scale).

\subsection{Clay minerals}

Clay-size material was separated from the rocks after removing the cements - carbonates, organic matter and iron oxides (Jackson, 1975). Two clay fractions $<2 \mu \mathrm{m}$ and $<0.2 \mu \mathrm{m}$, were collected by centrifugation for determination of an illite crystallinity and expandability of illite-smectite respectively. Oriented slides were analysed both air-dry and after vapour glycolation $\left(10 \mathrm{~h}\right.$. at $60^{\circ} \mathrm{C}$, then $2 \mathrm{~h}$. at $\left.20^{\circ} \mathrm{C}\right)$ by $\mathrm{X}-$ ray diffraction: Philips diffractometer PW 1830 (generator) and PW 3020 (goniometer) with $0.02^{\circ}$ step from 2 to $30^{\circ} 2 \Theta$. Illite crystallinity index (IC) was measured as peak width in $\Delta^{\circ} 2 \Theta$ at half maximum (PWHM) of the 001 basal reflection of illite (Kübler, 1967) using background stripping and peak-fitting. The IC values were calibrated using international standards (Warr and Rice, 1994). Chlorite 002 was evaluated following Árkai et al. (1995) when illite was absent. Illite-smectite expandability was evaluated using NEWMOD program by Reynolds (1985) and diagrams by Środoń and Eberl (1984).

\subsection{Thermal modelling}

Burial and thermal history was simulated using the Petromod 1-D (IES) modelling software based on principles summarised by Welte and Yalçin (1988) and further explained in details by Poelchau et al. (1997) and Yalçin et al. (1997). Present steady-state or corrected subsurface temperature and heat flow data of Čermák (1977a) and Hurtig et al. (1991) were used as an input. The lower boundary conditions in the thermal model are given by evolving heat flow at the base of the sedimentary basin fill. The upper boundary conditions are controlled by palaeo-climate and temperature at the sediment/water interface. The forward modelling method takes into consideration a continuous compaction and change of the thermal field through geological time. The increase of vitrinite reflectance is calculated as a function of temperature and time using equations of chemical kinetics (Sweeney and Burnham, 1990). The model is run many times with various values of palaeo-heat-flow and palaeo-depth of burial and is considered possible when the calculated trend of vitrinite reflectance with depth fits the measured data. 


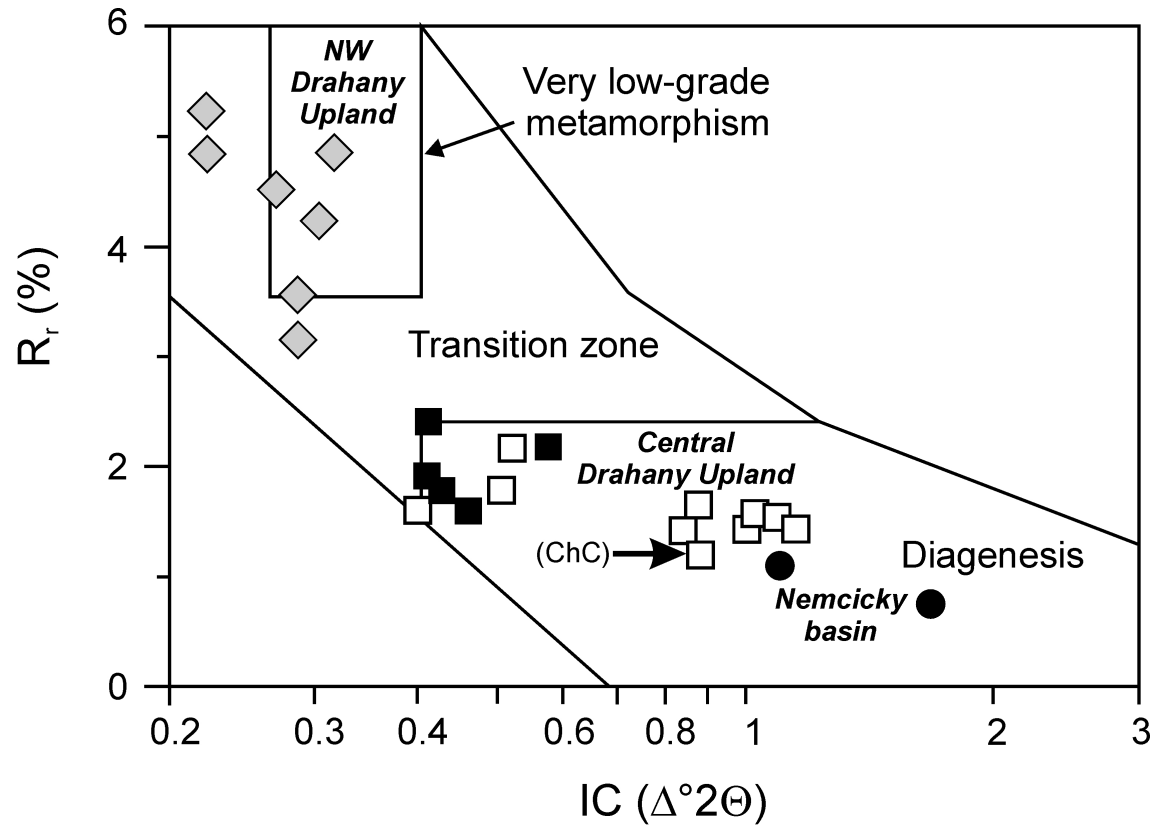

Fig. 5. Correlation of the illite crystallinity index (IC) and random vitrinite reflectance $\left(\mathrm{R}_{\mathrm{r}}\right)$ representing partial areas of the studied region (Fig. 4). Empty boxes are calcareous shales and siltstones. The envelopes refer to the reanges of published data from other basins. The arrow indictes the equivalent illite crystallinity derived from the chlorite $\mathrm{ChC}$ value.

\section{Results}

The earlier $R_{\max }$ data from this region include 5 (Dvorák and Wolf, 1979) and 19 samples (Dvořák, 1989; Krejčí et al., 1994) respectively. The newly measured 133 samples give more detailed regional distribution of the thermal maturity and are based on more measurements per sample (Fig. 4). The reliability of the thermal maturity data is verified on selected samples by parallel analyses of organic matter and clay minerals. The trend of the measured vitrinite reflectance $\left(\mathrm{R}_{\mathrm{r}}\right)$ and illite crystallinity (IC, Fig. 5) falls within the correlation band observed in other basins (e.g. Duba and Williams-Jones, 1983; Árkai and Lelkes-Felvari, 1993; Henrichs, 1993; Underwood et al., 1993; for review see Francu et al., 1999). The applied boundaries of diagenetic through very low-grade to low-grade metamorphic zones follow the values of Robert (1988) and Merriman and Peacor (1999). These parameters indicate a wide span of palaeo-thermal stress decreasing from NW to SE (Fig. 4). Three groups of data plot together in Figs. 4 and 5. The highest maturity with $R_{r}$ of $3.1-5.5 \%$ and IC $=0.22-0.38^{\circ} 2 \Theta$ occurs in the northern part of the studied region. A jump to lower thermal maturity $\left(\mathrm{R}_{\mathrm{r}}=\right.$ $1.2-2.5 \%$ and $\left.\mathrm{IC}=0.38-0.46^{\circ} 2 \Theta\right)$ is observed in the central part, south of a boundary going from Blansko to Prostejov and cutting across the lithostratigraphic units (dashed line in Fig. 4). Within this group a set of samples from Mokrá and Horakov (east of Brno) yield a broad range of IC values $\left(0.40-1.15^{\circ} 2 \Theta\right)$ while the $R_{r}$ vary in a narrow range (open squares in Fig. 5). The less consistent clay parameters are related carbonate lithology where the detrital illite predominates over the newly formed illite even in the very fine grain size fraction. The lowest thermal maturity was measured in the SE in the Palaeozoic below the overhtrust of the West Carpathians.

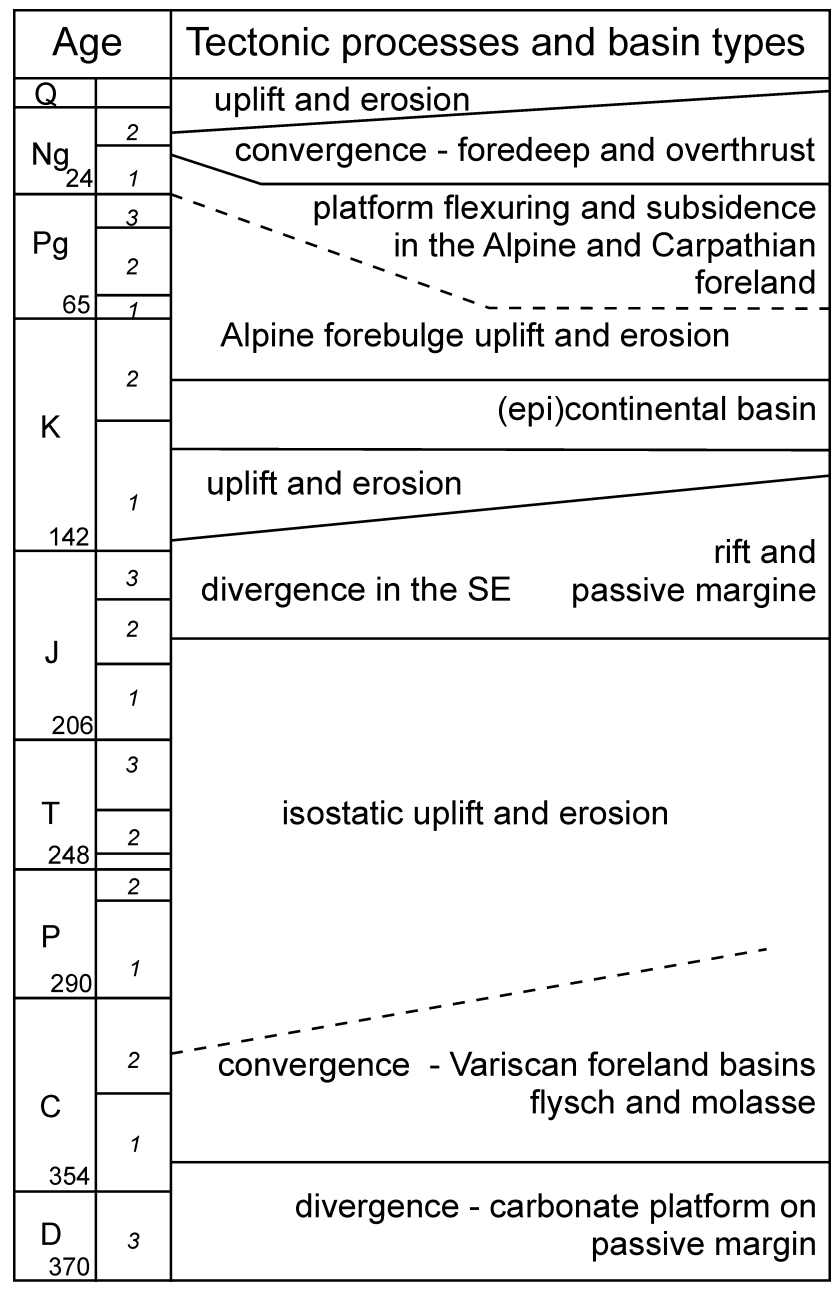

Fig. 6. Basic mechanisms controlling basin subsidence and inversions in the geological history of the SE Bohemian Massif. Ages after Gradstein and Ogg (1996). 


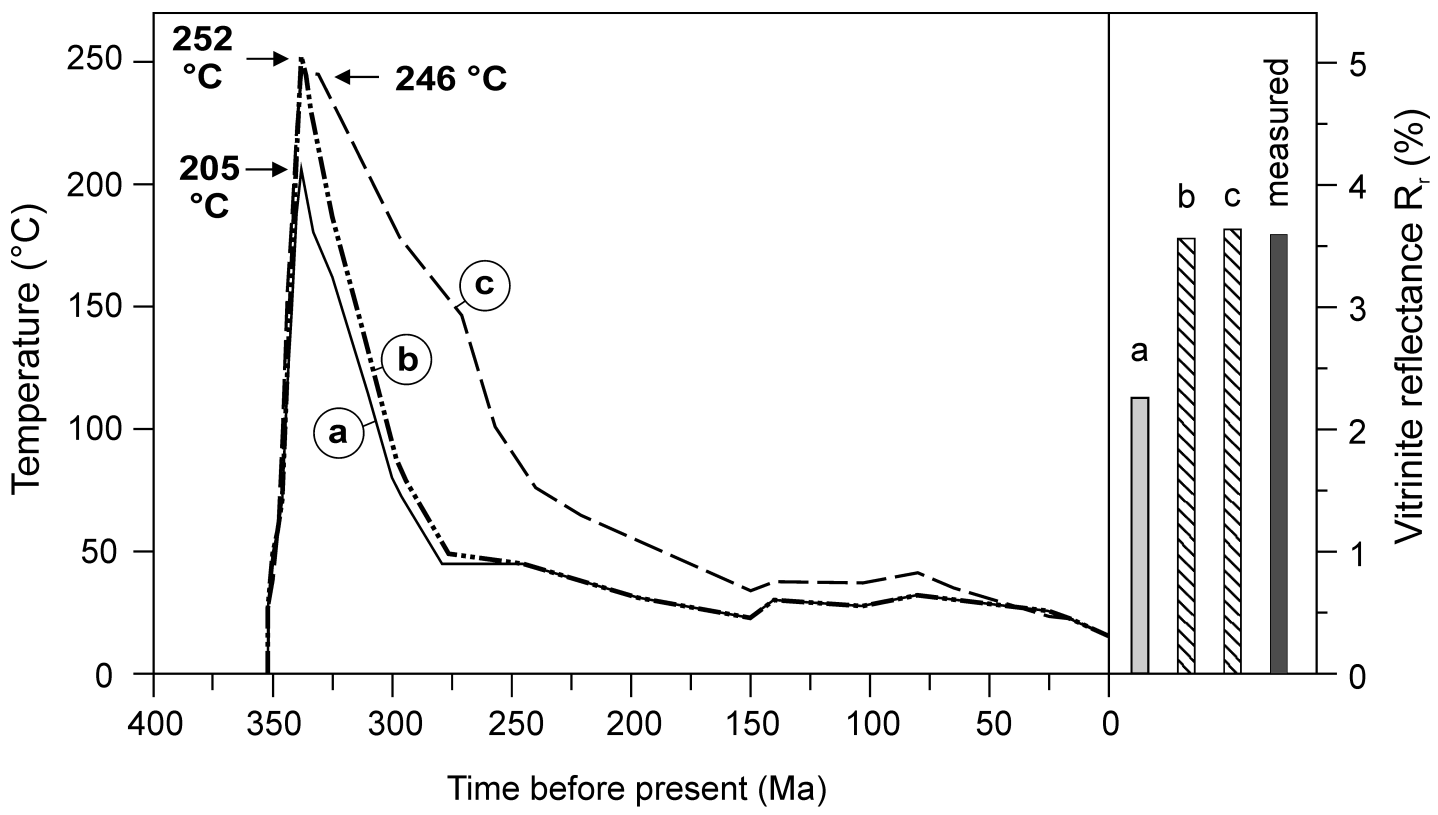

Fig. 7. Three forward models of thermal history of the deepest sample in the KDH-1 borehole profile: the calculated vitrinite reflectance using chemical kinetics (method of Sweeney and Burnham, 1990 and PetroMod 1-D program) is compared with the measured value.

Modelling was applied to quantify the thermal exposure and possible burial depth in these partial areas. It is based on the concept of the principal evolution phases with changing tectonic settings and related basin types as proposed in Fig. 6. The absolute ages are after Gradstein and Ogg (1996). The scenarios of the relative heat flow (q) changes in the model are tentatively chosen to follow the general trend in crustal extension (increase in q) and/or compression (decrease in q). Four model localities (Figs. 2 and 4) were selected to characterise the spatial relationships between the maximum burial depth within the Variscan orogeny, thermal exposure and later uplift.

\subsection{The Northern sector}

The $\mathrm{N}$ part of the Drahany Upland consists of the earliest Variscan flysch and the pre-flysch formations, i.e. Devonian to Lower Carboniferous slates and carbonates (Fig. 3). The vitrinite reflectance (Figs. 4, 5) in 75 samples from outcrops and shallow boreholes (50-250 m) suggest together with the illite crystallinity a thermal maturity equivalent to very lowgrade metamorphism (Fig. 5). The differences in $\mathrm{R}_{\mathrm{r}}$ among the samples are lower than the standard deviations of the data populations. No convincing steep maturation trend with present depth is observed either in KDH-1 or in the other 23 wells in this partial area. In the map of thermal maturity of the Visean flysch and pre-Visean units (marked separately in Fig. 4) the $R_{r}$ data do not show any systematic regional trend within this sector. This is interpreted as a result of similar palaeo-thermal exposure of the rocks in the entire northern sector.

Thermal history is evaluated with alternative scenarios using a kinetic algorythm deviced for calculation of vitrinite maturation as a function of temperature and time (Sweeney and Burnham, 1990). The empirical polylines in Fig. 7 with different heating and cooling stages show the absolute temperature affecting the rocks at the base of the Protivanov Fm. (earliest Variscan flysch) in the KDH-1 borehole profile. Heating of rocks up to $205^{\circ} \mathrm{C}$ (Fig. 7a) yields maturity of only $2.2 \% \mathrm{R}_{\mathrm{r}}$, i.e. by $1.5 \%$ lower than the measured vitrinite reflectance (Fig. 7 right). Both temperature-time curves (b) and (c) in Fig. 7 with maximum palaeo-temperature of 252 and $246^{\circ} \mathrm{C}$ respetively yield thermal maturity similar to the measured $R_{r}$ data. The (c) scenario makes the same maturity as (b) with a cca. double exposure time within the top $10^{\circ} \mathrm{C}$ interval $\left(236-246^{\circ} \mathrm{C}\right)$ and by $6^{\circ} \mathrm{C}$ lower maximum paleo-temperature $\left(246^{\circ} \mathrm{C}\right)$. The slower cooling phase in $(\mathrm{c})$ shows no visible effect on vitrinite reflectance.

The three curves in Fig. 7 represent partial outputs of 1-dimensional models of palaeo-heat flow and amount of burial and uplift (Fig. 8a, b, c). Each model yields a calculated maturity trend with depth, which is compared with the measured vitrinite reflectance. The first scenario (Fig. 8a) is conceived to get as close as possible to a shallow burial associated with extraordinary high palaeo-gradient as proposed by Dvořák (1989) or Dvořák et al. (1997). An empirical palaeo-heat flow of $140 \mathrm{~mW}^{*} \mathrm{~m}^{-2}$ yields in carbonaceous siliciclastic lithologies a temperature distribution with palaeo-gradient of $123^{\circ} \mathrm{C} / \mathrm{km}$ and $97^{\circ} \mathrm{C} / \mathrm{km}$ at depth intervals of 0-1 and 1-2 km respectively. Such values are worldwide possible in ocean ridges, active rift and volcanic areas (Allen and Allen, 1990). The modelling results show that a burial to depth of $1.5 \mathrm{~km}$ and temperature of $205^{\circ} \mathrm{C}$ (Fig. 7a) is too shallow to produce the observed metamorphism even under such high geothermal conditions. 


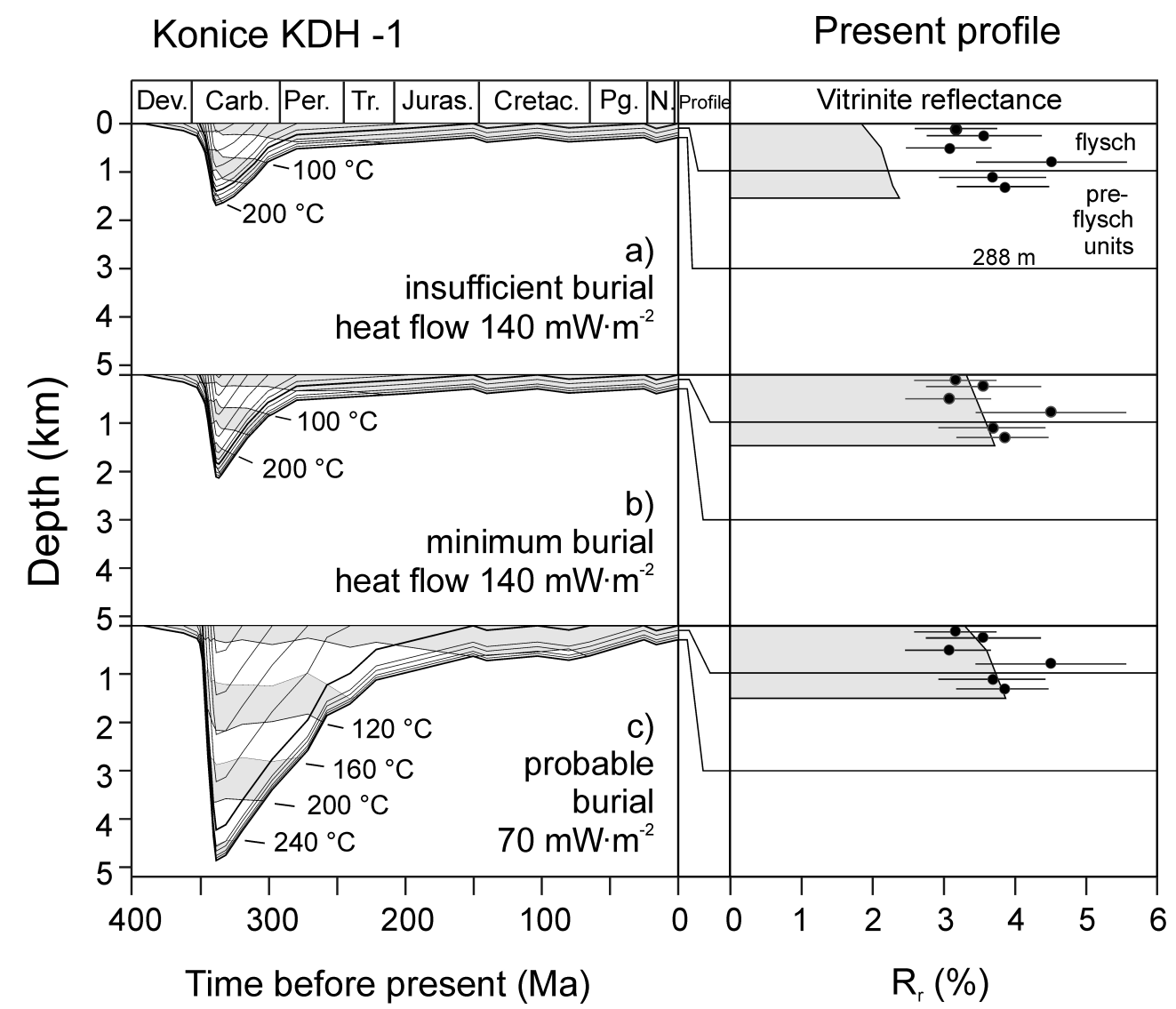

Fig. 8. Burial and thermal history scenarios of the KDH-1 borehole profile (Konice area) and their calibartion by measured vitrinite reflectance $\left(\mathrm{R}_{\mathrm{r}}\right)$.

Table 1. Sensitivity analysis of different Carboniferous burial and thermal scenarios for the Nem-2 well

\begin{tabular}{lccc}
\hline $\begin{array}{l}\text { Model(Nem-2) } \\
\text { Fig. } 9\end{array}$ & $\begin{array}{c}\text { eroded } \\
\text { units }(\mathrm{km})\end{array}$ & $\begin{array}{c}\text { heat flow } \\
\left(\mathrm{mW} / \mathrm{m}^{2}\right)\end{array}$ & $\begin{array}{c}\text { geothermal gradient } \\
\left({ }^{\circ} \mathrm{C} / \mathrm{km}\right) \\
\text { between } 2-4 \mathrm{~km}\end{array}$ \\
\hline A (hot) & 1.1 & 95 & 58 \\
\hline B (cold) & 2.0 & 45 & 27 \\
\hline C (optimum) & 1.6 & 63 & 37 \\
\hline
\end{tabular}

Additional burial is simulated using the same heat flow $\left(140 \mathrm{~mW}^{*} \mathrm{~m}^{-2}\right)$ in the model shown in Fig. 8 b. The resulting trend of calculated $R_{r}$ with depth fits quite closely the measured borehole data. The interpretation is that depth of $1.9 \mathrm{~km}$ may be considered as the lowermost limit of the burial while the justification of such a heat flow remains open to discussion.

An alternative model (Fig. 8c) implies a palaeo-heat flow of $70 \mathrm{~mW}^{*} \mathrm{~m}^{-2}$ which is slightly above the worldwide average (Allen and Allen, 1990). From the calibration it follows that burial to more than $4.5-5 \mathrm{~km}$ (decompacted) is necessary to match the real data. The scenario (c) may be considered rather as a mean than an upper limit and a model with burial to $9 \mathrm{~km}$ with $40 \mathrm{~mW}^{*} \mathrm{~m}^{-2}$ produces only a slightly different result from that in Fig. 8c.

\subsection{Central and SE part of the Drahany Upland}

The surface geology of the central and SE parts of the Drahany Upland does not differ significantly in lithology and lithostratigraphy from the northern sector while the thermal maturity is distinctly lower and correspond to the late diagenetic alteration (wet and dry gas zones of Tissot and Welte, 1984).

Two borehole profiles are modelled in the area. The borehole Skalka BJ-10 situated S of Prostejov encountered the flysch unit (Myslejovice Fm.). The model of burial history in general is similar to that of the KDH-1 profile. The calibration by vitrinite reflectance of 1.77 a $2.09 \% \mathrm{R}_{\mathrm{r}}$ at depths of 51 and $110 \mathrm{~m}$ respectively suggests that erosional thickness is $4.8 \mathrm{~km}$ associated with palaeo-heat flow of $62 \mathrm{~mW} \mathrm{~m}^{-2}(3.5-$ $5.7 \mathrm{~km}^{2} 5$ and $50 \mathrm{~mW} \mathrm{~m}^{-2}$ respectively). The second modelled borehole, Slavkov-2 is situated next to the overthrust front of the West Carpathian Flysch Belt. It encounters the Devonian to Tournaisian basal clastics and carbonates (49$1320 \mathrm{~m}$ ) and the Lower Miocene of the Carpathian Foredeep 


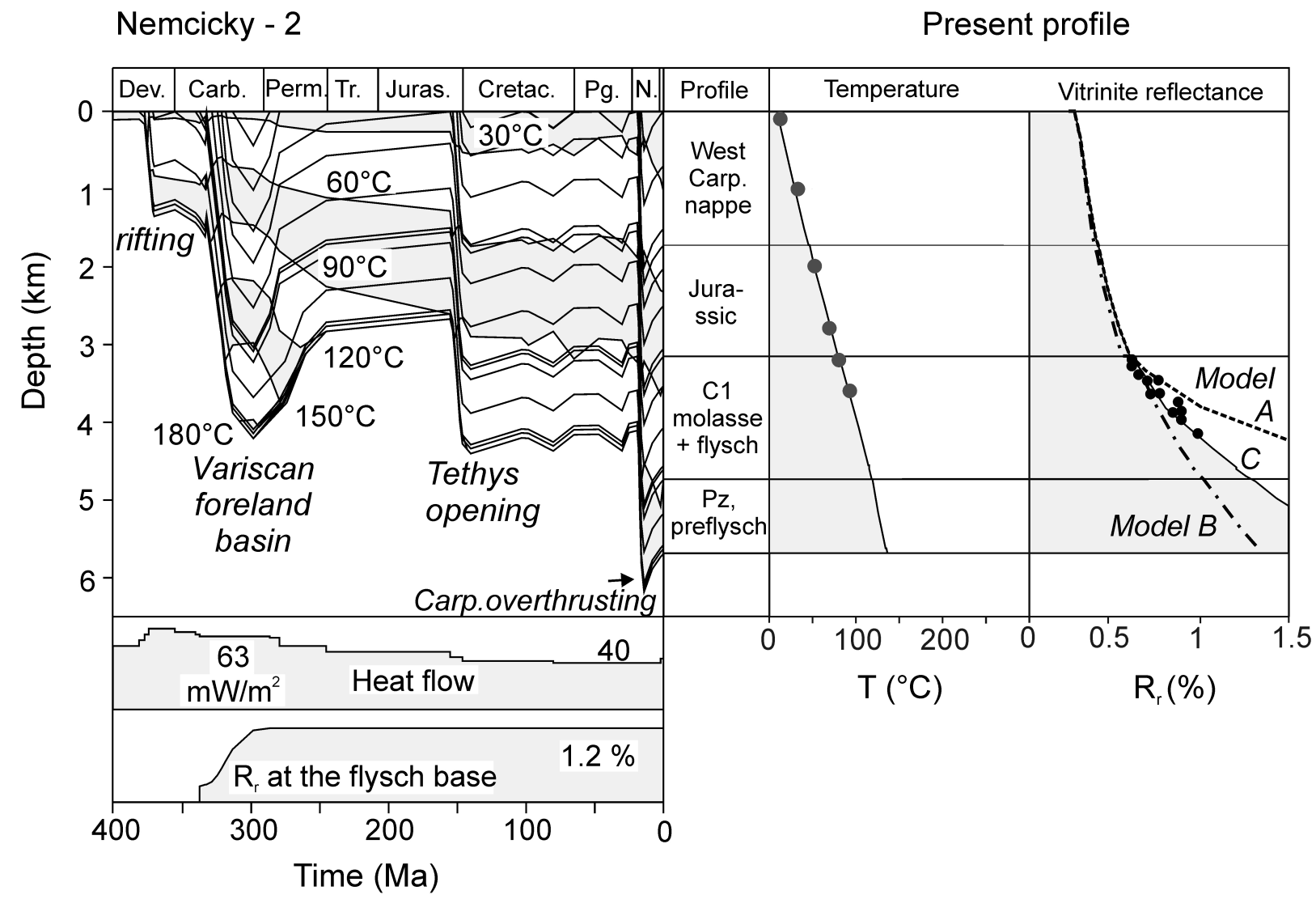

Fig. 9. Burial and thermal history of the Nem-2 borehole profile. Calibration data are depicted in the Upper Carboniferous part of the profile. Sensitivity analysis is shown by three curves of the modelled vitrinite reflectance with depth (see Table 1).

$(0-49 \mathrm{~m})$. The $\mathrm{R}_{\mathrm{r}}$ data of 1.1 and $1.7 \%$ at depth of 136 and $1253 \mathrm{~m}$ respectively calibrate a model with $3.0 \mathrm{~km}$ erosion and $63 \mathrm{~mW} \mathrm{~m}^{-2}$.

\subsection{The Palaeozoic below the Carpathians}

This part of the Palaeozoic was encountered in numerous deep boreholes below the nappes of the Outer Carpathians. Devonian and Carboniferous sediments in the $\mathrm{S}$ and SE in this area have diagenetic illite/smectite with $23-35 \% \mathrm{~S}$ and $\mathrm{R}_{\mathrm{r}}=0.6-1.1 \%$. Organic matter maturity is equivalent to the oil window (Francu et al., 1996).

The borehole Nemcicky- 2 with almost $5.5 \mathrm{~km}$ total depth is newly modelled and considered representative for this area. The sedimentary record comprises Cambrian siliciclastics (Jachowicz and Přichystal, 1997), Devonian to Carboniferous carbonates (Macocha and Lišen Fms.), relatively thin flysch (50 m of Myslejovice Fm.) and over $1000 \mathrm{~m}$ of Variscan molasse. Unconformities indicate erosional events within the Lower Carboniferous carbonates (Lišen Fm.) and between the Palaeozoic and the overlying autochthonous Jurassic marls.

The erosion of the uppermost Carboniferous units was followed by deposition and erosion of Mesozoic and Tertiary sediments and emplacement of West Carpathian thrust sheets (Krejčí et al., 1996). From the low coalification gradients within Jurassic, Paleogene and Neogene units in this area (Francu et al., 1996) it may be concluded that the heat flow during the Jurassic, and Tertiary did not exceed the maximum ones during the Late Carboniferous (Fig. 9). Calibration of the model by vitrinite reflectance of $0.60-0.94 \%$ at depth range of 3204-4664 (Fig. 9) suggests erossion of $1600 \mathrm{~m}$ and $63 \mathrm{~mW} \mathrm{~m}^{-2}$ during the Late Carboniferous. The sensitivity analysis was applied to evaluate the effect of different heat flow at the basin fill / basement boundary and the thickness of the eroded Palaeozoic units. The upper and lower limits (Table 1) were tested under a chosen condition that the thermal maturity at the top of the preserved Carboniferous fits the calibration data. The A and B models only fit about half of the calibration data and deviate from the data trend at greater depth. These alternatives are exagerated and probable values of deviations from the optimum input parameters may by half narrower.

\section{Interpretation and discussion}

The measured vitrinite reflectance in shallow boreholes in northern and central sectors of the studied area do not allow to make strict conclusions on the palaeogradient. It is, however, possible to assess the firm and weak points in the alternative concepts of geological and geothermal evolution. 


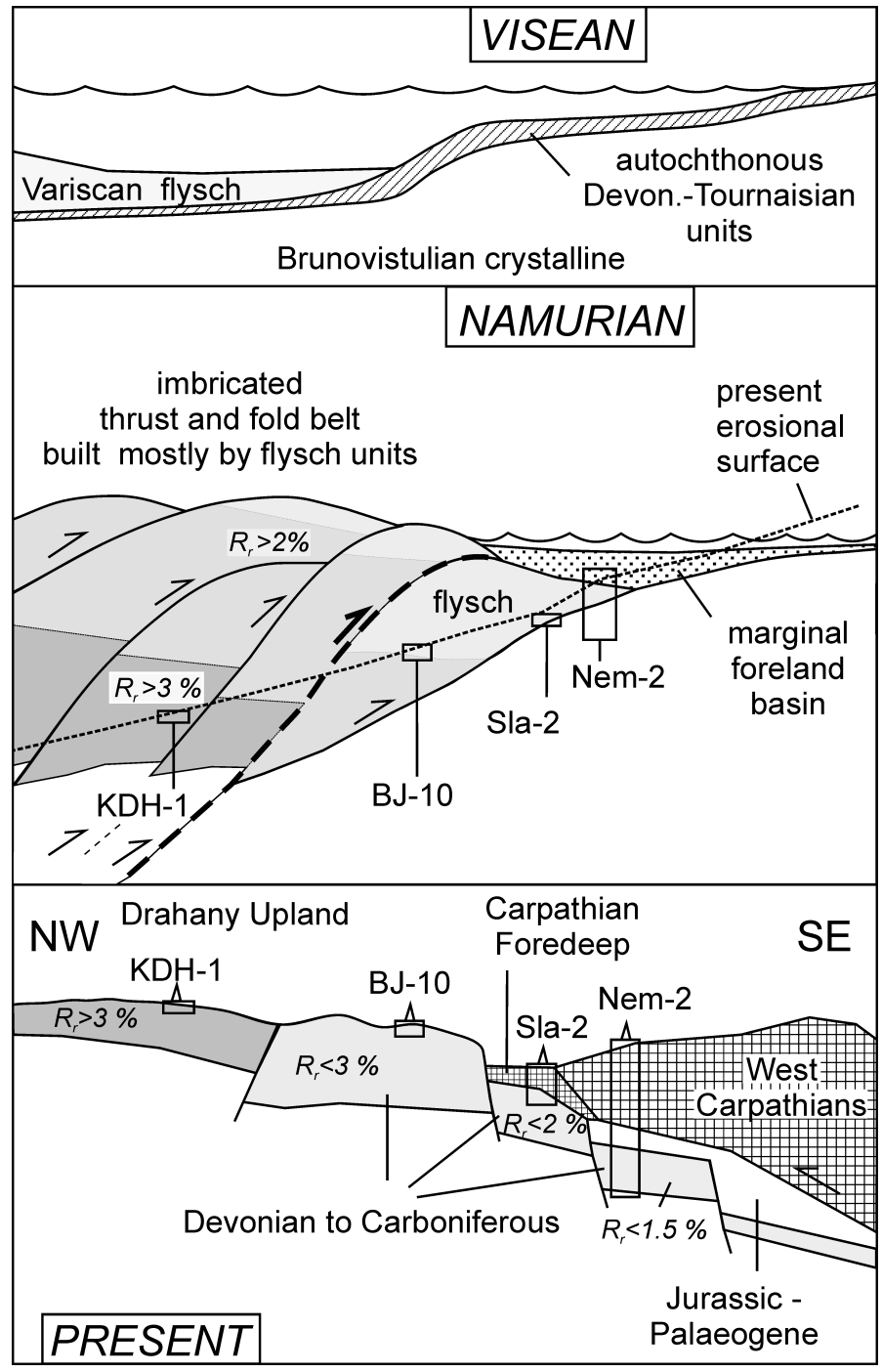

Fig. 10. Tectonic sketch (vertically not to scale) of the frontal Variscan fold and thrust belt and foreland basin in the Visean, Namurian and present. Wells with modelled burial histories are shown. The shaded areas represent thermal maturity ranges given by vitrinite reflectance $\left(\mathrm{R}_{\mathrm{r}} \%\right)$.
According to the first scenario, the Rheno-Hercynian Palaeozoic units in SE Czech Republic formed at shallow burial and under increasing palaeo-geothermal gradient from $90^{\circ} \mathrm{C}_{\mathrm{km}}^{-1}$ in the foreland to $200^{\circ} \mathrm{C} \cdot \mathrm{km}^{-1}$ in the hinterland (e.g. Dvořák, 1989, Dvořák et al., 1997). The other concept emphasises considerable vertical movements during the last phases of the Variscan orogeny.

Mere recalculation of the vitrinite reflectance to maximum palaeo-tempearture (e.g. Fig. 7) gives values ranging from 220 to $290^{\circ} \mathrm{C}$ in the northern sector and from 120 to $180^{\circ} \mathrm{C}$ in the central area with a gap of $40^{\circ} \mathrm{C}$ at the BlanskoProstejov line. Numeric simulation of continuously changing regional palaeo-heat flow does not produce such a more or less monotonous diagenetic-to-metamorphic pattern within the partial areas and such a contrast at their boundary.

The experience from other regions and calculations show that stacking of thrust sheets in frontal accretion wedges brings a relative decrease of the geothermal gradient (Angevine and Turcotte, 1983; Wygrala et al., 1990). As the extent of deformation and thrusting within this part of
Rheno-Hercynian zone increases from the frontal part (S-SE) to the internal zone (N-NW), one can imply that the palaeogradients would rather decrease than increase in this direction.

In the proposed models the assumed deep burial was caused by additional deposition of a thicker flysch sedimentary pile, possibly followed by emplacement of the frontal part of the Variscan orogenic wedge from the NW during the Viséan and Late Carboniferous. The accretion mechanism with compression and shortening would first increase the burial and later cause detachment, imbrication, and exhumation of the earlier buried strata within the advancing orogenic complex (Fig. 10). It is possible to attribute the sudden jump in thermal maturity at the Blansko-Prostejov line to post-diagenetic/metamorphic movements with a more profound uplift and erosion of the northern sector in respect to the central Drahany Upland (Fig. 10). The inverted diagenetic or metamorphic zonation formed in this way with higher-grade in the rear and top and lower-grade rocks below and towards the foreland has been observed in several other 
orogenic systems (Houseknecht and Matthews, 1985; Fritz et al., 1996; Warr and Greiling, 1996; Merriman and Frey, 1999).

Thin-skinned overthrusting associated with RhenoHercynian orogenic wedge propagation in the MoravianSilesian zone about 50-100 km NW of the Drahany Upland was characterised by Cháb et al. (1984), Č́ižek and Tomek (1991), Kumpera and Martinec (1995), and Hladil et al. (1999). The new data and modelling suggest that this type of tectonics could play an important role also in the Drahany area.

The amplitude of uplift and thickness of the eroded Upper Palaeozoic units decrease from $4.5-9 \mathrm{~km}$ in the north to about $4.6(3.5-5.7) \mathrm{km}$ in the central part, and $1.6(1.1-2.0) \mathrm{km}$ in the frontal Rheno-Hercynian zone and associated foredeep in the SE. The magnitude of erosion implies that the Palaeozoic units extended further to the south and east and also covered the crystalline of the Brno Massif (Fig. 2) which was later uplifted and exposed at the surface.

The calculation of the palaeo-geothermal gradient in Late Carboniferous Upper Silesian Basin (200 km NE of the Drahany Upland) published by Šafanda et al. (1991) using the Buntebarth method resulted in a very high gradient of $95^{\circ} \mathrm{C} / \mathrm{km}$ and partly open question of the amount of erosion. Our results of the finite-element forward modelling offer a geological history with palaeo-geothermal gradients of 31$39^{\circ} \mathrm{C} / \mathrm{km}(0-4 \mathrm{~km})$ and heat flow densities of $50-65 \mathrm{~mW} / \mathrm{m}^{2}$ during maximum burial. Using the relationships given by Čermák (1977b) these values would correspond to Palaeozoic crustal thickness of $30 \mathrm{~km}$ in the Variscan foredeep basin and $40 \mathrm{~km}$ in the thin-skinned orogenic wedge.

\subsection{Comparison with analogous basins and thrust belts}

A similar geological setting has been studied in the Ruhr area where Devonian to Upper Carboniferous formations are partly covered by the low-thermally mature Cretaceous. Littke et al. (1994), Büker et al. (1995) and Littke et al. (2000) used vitrinite reflectance, 1-D and 2-D modelling programmes and documented an increase of the palaeo-heat flow from the orogenically thickened crust in the south towards the Rheno-Hercynian foreland with relatively thinner crust. Based on vitrinite coalification trends and modelling they calculated eroded thicknesses of the Westphalian to Stephanian from $6 \mathrm{~km}$ in the south (Rheno-Hercynian) to $2.5 \mathrm{~km}$ in the more external foreland basin (Ruhr Basin) in the north. Due to erosion the present coalification rank at the surface is higher in the hinterland than in the foreland even though the palaeo-geothermal gradient decreases in the opposite direction.

A $10 \mathrm{~km}$ deep burial of Upper Carboniferous strata and later uplift associated with the Ouachita orogenesis (300 Ma) in Oklahoma were calculated by Houseknecht and Matthews (1985) using vitrinite reflectance as thermal maturity parameter. A close relationship of the foreland propagating thrust wedge and the decreasing metamorphic grade and diagenesis from the rear to the frontal part and autochthonous under- thrust substratum was documented in the external Variscides in Southwest England (Warr et al. 1991). The above mentioned case histories and the area studied in this paper are consistent in several aspects and document a more general validity of the observed diagenetic patterns and the respective thermal models related to the Variscan orogeny.

\section{Conclusions}

1. Newly measured vitrinite reflectance document more densely the diagenetic to very low-grade metamorphic pattern in the SE end of the Rheno-Hercynian zone. The juxtaposed high and intermediate values of vitrinite reflectance along the boundary between Blansko (Sloup) and Prostejov in the central part of the Drahany Upland suggest a significant postdiagenetic tectonic activity and uplift. More detailed structural investigation of this line is needed.

2. A general stepwise decrease in metamorphic grade and diagenesis of the siliciclastic rocks in the Palaeozoic of the SE Bohemian Massif towards the frontal zone of the Variscan fold and thrust belt gives evidence of a close relationship of the thermal alteration and the RhenoHercynian thin-skinned thrust wedge propagation. The present geographic orientation of the described trends and orogenic front may be different from that during the Carboniferous.

3. The present distribution of the vitrinite reflectance and illite crystallinity can be explained by a model of a deeper, mainly tectonically driven burial with lower heat flow in the rear Rheno-Hercynian zone and relatively shallower sedimentary burial with equal or slightly higher heat flow in the foreland basin. During the orogenic wedge propagation, the subsidence and burial migrated with time towards the foreland and was probably associated with uplift of the thrust sheets in the rear.

4. The regional metamorphic and diagenetic pattern and basin modelling suggests that the diagenetic and very low-grade metamorphic grade could not be attained merely by high gradients without significant burial and erosion. The calculated values of the eroded thickness range from $4-9 \mathrm{~km}$ in the fold-and-thrust belt in the present north to $1.6 \mathrm{~km}$ in the marginal foreland basin in the south-east.

5. The presented data show similar features regarding the metamorphic and diagenetic patterns in respect to geometry of orogenic belts and their forelands observed in the Ruhr Basin, Rhenish Massif, external Variscides in Southwest England, and Ouachita Mountains. The modelling shows that the magnitude of probable erosion is similar in the mentioned segments of the Ouachita and Rheno-Hercynian zones. 
Acknowledgements. This research benefited from EUROPROBE, a programme of the European Science Foundation. The authors wish to thank J. Hladil, D. H. Welte, V. Čermák, Z. Stráník, and O. Krejčí for stimulating discussions, and R. F. Sachsenhofer for reviewing and critical comments.

\section{References}

Allen, P. A. and Allen, J.: Basin Analysis: Principles and Applications, Blackwell, London, 451, 1990.

Angevine, C. L. and Turcotte D. L.: Oil generation in overthrust belts, The AAPG Bulletin, 67, 235-241, 1983.

Árkai, P. and Lelkes-Felvari, G: The effect of lithology, bulk chemistry and modal composition on illite "crystallinity" - a case study from the Bakony Mts., Hungary, Clay Min., 28, 417-433, 1993.

Árkai, P., Sassi, F. P., and Sassi, R.: Simultaneous measurements of chlorite and illite crystallinity: a more reliable tool for monitoring low-to very low grade metamorphism in metapelites. A case study from the Southern Alps (NE Italy), Eur. J. Mineral., 7, 1115-1128, 1995.

Barker, C.: Thermal modelling of petroleum generation: theory and applications, Elsevier Science B. V., Amsterdam, 1-512, 1996.

Bostick, N. H.: Microsopic measurements on the level of catagenesis of solid organic matter in sedimentary rocks to aid exploration for petroleum and to determine former burial temperatures - a review, Soc. Econ. Paleont. Miner., Spec. Publ., 26, 17-43, 1979.

Büker, C, Littke, R., and Welte, D.: 2D-modelling of thermal evolution of Carboniferous and Devonian sedimentary rocks of the eastern Ruhr basin and northern Rhenish Massif, Germany, Z. deut. geol. Ges., 146, 321-339, 1995.

Buntebarth, G.: The degree of metamorphism of organic matter in sedimentary rocks as a paleothemometer applied to the Upper Rhine Graben. - Pageo. 117, 83-91, 1978.

Buntebarth, G.: Geothermal history estimated from the coalification of organic matter, Tectonophysics, 83, 101-108, 1982.

Čermák, V.: Heat flow map of the Bohemian Massif, J. Geoph., 42, 455, 1977a.

Čermák, V. and Bodri, L.: Time-dependent crustal temperature modelling: Central Alps, Tectonophysics, 257, 7-24, 1996.

Čermák, V.: Relation between heat flow and crustal thickness, Acta Geol. Acad. Scient. Hungaricae, 21, 4, 261-263, $1977 \mathrm{~b}$.

Č́žzek, P. and Tomek, C.: Large-scale thin-skinned tectonics in the eastern boundary of the Bohemian Massif, Tectonics, 10, 2, $273-$ 286, 1991.

Cháb, J., Fišera, M., Fediuková, E., Novotný, P., Opletal, M., and Skácelová, D.: Problems of tectonic and metamorphic evolution of the eastern part of the Hrubý Jeseník Mts., Sbor. geol. ved, Geol., 39, 27-72, 1984.

Duba, D. and Williams-Jones, A. E.: The application of illite crystallinity, organic matter reflectance, and isotopic techniques to mineral exploration: a case study in southwestern Gaspe Quebec, Econ. Geol., 78, 1350-1363, 1983.

Dvořák, J.: Anchimetamorphism in the Variscan tectogene in Central Europe - its relationship to tectogenesis, Vest. ÚÚG, 64, 1, 17-30, 1989.

Dvořák, J.: Stratigraphy, in: Dallmeyer, R. D., Franke, W., and Weber, K. (Eds.): Pre-Permian geology of Central and Eastern Europe, Springer-Verlag, Berlin - Heidelberg - New York, 479489, 1995.
Dvořák, J., Honek, J., Pešek, J., and Valterová, P.: Deep borehole evidence for a southward extension of the Early Namurian deposits near Nemcicky, S. Moravia, Czech Republic: implication for rapid coalification, in: Gayer, R. and Pešek, J. (Eds.): European Coal Geology and Technology, Geological Society Special Publication No. 125, 179-193, 1997.

Dvořák, J. and Skoček, V.: Reconstruction of the paleo-heat flow regime in two areas of the Variscan orogene, N. Jb. Geol. Paläont. Mh. 9, 517-527, 1975.

Dvořák, J. and Wolf, M.: Thermal metamorphism in the Moravian Paleozoic (Sudeticum, ČSSR), N. Jb. Geol. Paläont. Mh., 10, 596-607, 1979.

Ellenberger, F. and Tamain, A. L. G.: Hercynian Europe, Episodes 1, 22-27, 1980.

Finger, F. and Steyrer, H. P.: A tectonic model for the eastern Variscides: Indications from a chemical study of amphibolites in the south-eastern Bohemian Massif, Geologica Carpathica, 46, 137-150, 1995.

Francu, E.: Optical properties of organic matter in Devonian and Lower Carboniferous black shales in the northern Drahany Upland, Bull. of Czech Geol. Soc., 75, 2, 115-120, 2000.

Francu, E., Francu, J., and Kalvoda, J.: Illite crystallinity and vitrinite reflectance in Paleozoic siliciclastics in the SE Bohemian massif as evidence of the thermal history, Geologica Carpatica, 50, 5, 365-372, 1999.

Francu, J., Radke, M., Schaefer, R. G., Poelchau, H. S., Č́slavský, J., and Bohácek, Z.: Oil-oil and oil-source rock correlations in the northern Vienna Basin and adjacent Carpathian Flysch Zone (Czech and Slovak area), in: Wessely, G. and Liebl, W. (Eds.): Oil and gas in alpidic thrust belts and basins of Central and Eastern Europe, EAGE Spec. Publ. No. 5, 343-353, 1996.

Franke, W.: Tectonostratigraphic units in the Variscan belt of central Europe, in: Dalmeyer, R. D. (Ed.): Terranes in the circumAtlantic Palaeozoic orogens, Geol. Soc. Am. Spec. Paper, 230, 67-90, 1989.

Fritz, H., Dallmeyer, R. D., and Neubauer, F.: Thick-skinned versus thin-skinned thrusting: Rheology controlled thrust propagation in the Variscan collisional belt (The souteastern Bohemian Massif, Czech Republic - Austria), Tectonics, 15, 6, 1389-1413, 1996.

Gradstein, F. M. and Ogg, J.: A Phanerozoic time scale, Episodes 19, 1-2, 3-5, 1996.

Hartley, A. J. and Otava, J.: Sediment provenance and dispersal in a dep marine foreland basin: the Lower Carboniferous Culm basin, Czech Republic, J. Geol. Soc., 158, 137-150, 2001.

Henrichs, C.: Sedimentographische Untersuchungen zur Hochdiagenese in der Kossen-Formation (obere Trias) der westlichen Ostalpen und angrenzender Südalpengebiete, Bochumer geol. u. geotechn. Arb., 40, 1-206, 1993.

Hladil, J., Krejčí, Z., Kalvoda, J., Ginter, M., Galle, A., and Beroušek, P.: Carbonate ramp environment of Kellwasser time interval (Lesní lom, Czechoslovakia), Bull. Soc. belg. Géol., 100, 1-2, 57-119, 1992.

Hladil, J., Melichar, R., Otava, J., Galle, A., Krs, M., Man, O., Pruner, P., Čejchan, P., and Orel, P.: The Devonian in the Easternmost Variscides, Moravia: a holistic analysis directed towards comprehension of the original context, Abh. Geol. B.-A., 54, 2447, 1999.

Houseknecht, D. W. and Matthews, S. M.: Thermal maturity of Carboniferous strata, Ouachita Mountains, The AAPG Bulletin, 69, 3, 335-345, 1985.

Hurtig, E., Čermák, V., Haenel, R., and Zui, V. (Eds.): Geothermal 
atlas of Europe, Hermann Haack Verlag, Gotha, 160pp, 1991.

Issler, D. R. and Beaumont, C.: A finite element model of the subsidence and thermal evolution of extensional basins: application to the Labrador continental margin, in: Naeser, N. D. and McCulloh, T. H. (Eds.): Thermal history of sedimentary basins. Methods and case histories, Springer, New York - Berlin - Heidelberg, 239-267, 1989.

Jackson, M. L.: Soil chemical analysis. Advanced course, published by the author, Dept. Soil Sci., Univ. Wisconsin, Madison, 1-895, 1975.

Jachowicz, M. and Přichystal, A.: Lower Cambrian sediments in deep boreholes in south Moravia, J. Czech Geol. Soc., 72, 4, (in Czech) 329-332, 1997.

Kalvoda, J.: Comments on possible levels for Lower Carboniferous subdivision and results from Moravia, Geobios, 27, 5, 615-619, 1994.

Krejčí, O., Francu, J., Müller, P., Pereszlenyi, M., and Stráník, Z.: Geologic structure and hydrocarbon generation in the Carpathian flysch belt of southern Moravia, J. Czech Geol. Soc., 69, 4, 1326, 1994.

Krejčí, O., Francu, J., Poelchau, H. S., Müller, P., and Stráník, Z.: Tectonic evolution and oil and gas generation model in the contact area of the North European Platform with the West Carpathians, in: Wessely, G. and Liebl, W. (Eds.): Oil and Gas in Alpidic Thrustbelts and Basins of Central and Eastern Europe, EAGE Spec Publ. No. 5, 177-186, 1996.

Kübler, B.: La crystallinite de l'illite et les zones tout a fait superieures du metamorphisme, in: Etages Tectoniques, Colloque de Neuchatel, 1966, A la Baconniere, Neuchatel, 105-122, 1967.

Kumpera, O. and Martinec, P.: The development of the Carboniferous accretionary wedge in the Moravian-silesian Palaeozoic Basin, J. Czech Geol. Soc., 40, 1-2, 47-64, 1995.

Littke, R., Büker, C., Lückge, A., Sachsenhofer, R. F., and Welte, D. H.: A new evaluation of palaeo-heat flows and eroded thicknesses for the Carboniferous Ruhr basin, western Germany, Int. J. Coal Geol., 26, 155-183, 1994.

Littke, R., Büker, C., Hertle, M., Karg, H., Stroetmann-Heinen, $\mathrm{V}$., and Oncken, O.: Heat flow evolution, subsidence and erosion in the Rheno-Hercynian orogenic wedge of central Europe, in: Franke, W., Haak ,V., Oncken, O., Tanner, D. (Eds.): Orogenic processes: Quantification and modelling in the Variscan Belt, 231-256, 2000.

Merriman, R. J. and Frey, M.: Patterns of very low-grade metamorphism in metapelitic rocks, in: Frey, M. and Robinson, D. (Eds.): Low-grade metamorphism, Blackwell Science, Oxford, 61-107, 1999.

Merriman, R. J. and Peacor, D. R.: Very low-grade metapelites: mineralogy, microfabrics and measuring reaction progress, in: Frey, M. and Robinson, D. (Eds.): Low-grade metamorphism, Blackwel Science, Oxford, 10-60, 1999.

Mísař, Z., Dudek, A., Havlena, V., and Weiss, J. Z.: Geology of Czechoslovakia I., Bohemian Massif, SPN, Praha, 380 pp (in Czech), 1983.

Poelchau, H. S., Baker, D. R., Hantschel, Th., Horsfield, B., and Wygrala, B.: Basin simulation and the design of the conceptual basin model, in: Welte, D. H., Horsfield, B., Baker, D. R. (Eds.): Petroleum and basin evolution, Springer, Berlin - Heidelberg New York, 5-70, 1997.

Reynolds, R. C.: NEWMOD a computer program for the calcu- lation of one-dimensional diffraction patterns of mixed-layered clays: Reynolds, R. C. and Brook, D., Hannover, New Hamshire, 1985.

Robert, P.: Organic metamorphism and geothermal history, ELFAquitaine and D. Reidl, Dordrecht, 311 pp, 1988.

Šafanda, J., Honek, J., Weiss, G., and Buntebarth, G.: Paleogeothermics in the Czechoslovak part of the Upper Silesian Basin, Geophys. J. Int., 104, 625-633, 1991.

Skoček, V.: Regional and geological interpretation of organic matter coalification in the Late Palaeozoic sediments of the Bohemian Massif, J. Czech Geol. Soc., 51, 13-24 (in Czech), 1976.

Środoń, J. and Eberl, D. D.: Illite, in: Bailey, S. W. (Ed.): Micas, Reviews in Mineralogy 13, Mineralogical Society of America, 495-544, 1984.

Sweeney, J. J. and Burnham, A. K.: Evaluation of a simple model of vitrinite reflectance based on chemical kinetics, AAPG Bull., 74, 1559-1570, 1990.

Teichmüller, M., Taylor, G. H., and Littke, R.: The nature of organic matter - macerals and associated minerals, in: Taylor, G. H., Teichmüller, M., Davis, A., Diessel, C.F. K., Littke, R., Robert, P. (Eds.): Organic petrology, Gebrüder Borntraeger, Berlin, 175274, 1998.

Tissot, B. P. and Welte, D. H.: Petroleum formation and occurrence, $2^{\text {nd }}$ edn. Springer, Berlin - Heidelberg - New York, 699pp, 1984.

Underwood, M. B., Laughland, M. M., and Kang, S. M.: A comparison among organic and inorganic indicators of diagenesis and low-temperature metamorphism, Tertiary Shimanto belt, Shikoku, Japan. Geol. Soc. Amer., Spec. Paper, 273, 45-61, 1993.

Ungerer, P., Burrus, J., Doligez, B., Chénet, P. Y., and Bessis, F.: Basin evaluation by integrated two-dimensional modelling of heat transfer, fluid flow, hydrocarbon generation, and migration, AAPG Bull., 74, 3, 309-335, 1990.

Vavrdová, M.: Acritarchs of Cambrian age in the basal clastics underlying the Moravian Devonian (Nemcicky-6 borehole), Zemní plyn a nafta, 42, 1, 31-32 (in Czech), 1997.

Waples, D. W.: Time and temperature in petroleum formation: application of Lopatin's method to petroleum exploration, AAPG Bull., 64, 916-926, 1980.

Warr, L. N. and Greiling, O. R.: Thrust-related very low grade metamorphism in the marginal part of an orogenic wedge, Scandinavian Caledonides, Tectonics, 15, 6, 1213-1229, 1996.

Warr, L. N., Primmer, T. J., and Robinson, D.: Variscan very lowgrade metamorphism in Southwest England: a diastathermal and thrust-related origin, J. metamorph. Geol., 9, 751-764, 1991.

Warr, L. N and Rice, H. N. A: Interlaboratory standardization and calibartion of clay mineral crystallinity and crystalite size data, J. metamorph. Geol., 12, 141-152, 1994.

Welte, D. H. and Yalçin, M. N.: Basin modelling - A new comprehensive method in petroleum geology, Adv. Organic Geochemistry, 13, 1-3: 141-151, 1988.

Wygrala, B. P, Yalçin, M. N., and Dohmen, L.: Thermal histories and overthrusting - application of numerical simulation technique. Advances in organic geochemistry 1989, Org. Geochem., 16, 267-285, 1990.

Yalçin, M. N., Littke, R., and Sachsenhofer, R. F.: Thermal history of sedimentary basins, in: Welte, D. H., Horsfield, B., Baker, D. R. (Eds.): Petroleum and basin evolution, Springer, Berlin Heidelberg - New York, 73-167, 1997. 